\title{
ISLAMIC LAW VIEWS ON HARSH PHYSICAL PARENTING: A Comparative Study
}

\author{
Oleh: Mutia Hasan¹, Achmad Musyahid, Abdi Wijaya \\ 1E-mail : mutmainnahhasann@gmail.com \\ Fakultas Syariah dan Hukum UIN Alauddin Makassar
}

\begin{abstract}
This research aims to educate children in ordering prayers in Islam and then analyze it in the child protection law. However, in general, Islam places more emphasis on gentleness, patience, and compassion than on violent ways in educating children, although in some instances showing disbelief and opposing children's mistakes is necessary, of course, correctly and appropriately. In the concept of Islamic law, violence has become an enjoyable theme to discuss. On the one hand, there is a hadith from the Prophet about educating children, which, if understood textually, raises the public perception of the necessity of violence in educating children. The Child Protection Law aims to guarantee and protect children and their rights to live, grow, develop and participate optimally following human dignity and protection from violence and discrimination.
\end{abstract}

Keywords: Islamic Law; Prayer; Child Protection Act

\section{INTRODUCTION}

Prayer is a commandment from Allah for his servant that begins with takbiratul ihram and ends with greetings, with certain conditions and harmony. Prayer is the pillar of religion and the spearhead of many acts of worship. Prayer is also the key to all human acts of worship in this world. Because the most important thing to count and be accounted for before Allah is prayer ${ }^{1}$. According to Imam Ahmad, another statement regarding prayer is: everything that has lost its ends means wholly disappeared. If a servant's prayer has been lost, his religion will also be lost. ${ }^{2}$.

Even this prayer command is mentioned in the word of Allah Almighty in (Surah Al-Baqarah / 2: 34.) which reads:

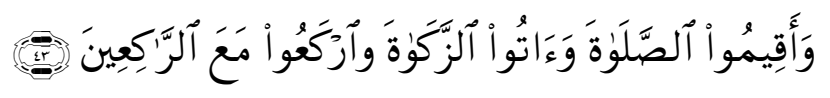

Meaning:

Establish prayer, pay alms-tax, ${ }^{1}$ and bow down with those who bow down.

\footnotetext{
1 Subhan Husain al-Husairi, Agar Anak Rajin Salat (Jogjakarta: Diva Press, 2011), h. 29.

2 Subhan Husain al-Husairi, Agar Anak Rajin Salat, h. 29.
} 
Prayer is the pillar of Islam. In other words, it is upright and sturdy and whether a person is Islamic depends on the pillar, namely prayer. Prayers must be instilled from an early age since the person is a child. Because parents first teach the practice of amaliah in Islam to their children (both boys and girls without exception) after tawhid is prayer, parents have to get their children accustomed to praying from an early age and teach the laws and ethics. This is done so that the children will grow up to be pious humans one day, namely people who obey all religious orders and obey in keeping away from their prohibitions. ${ }^{3}$

Rasulullah saw asked parents to be responsible for the formal and non-formal education of their children. Among these responsibilities are inviting children to pray, do good deeds, refrain from wrongdoing and inherit patience. Parents are required to educate their children to be able to worship Allah through education at home. The family has a responsibility towards children. Allah SWT orders parents to look after the family from hellfire by trying to make the family members carry out Allah's commands and prohibitions, including family members, in this case, our children. ${ }^{4}$. The order to protect themselves and their families from the torments of hellfire, when viewed from an educational point of view, means an order for Muslims to educate themselves and their families to have the mental strength that can withstand actions that will lead to error. ${ }^{5}$

Islam places more emphasis on gentleness, patience, and compassion than on violent ways in educating children, although in some instances showing disbelief and opposing children's mistakes is necessary, of course, correctly and adequately. In the concept of Islamic law, violence has become an enjoyable theme to discuss. On the one hand, there is a hadith from the Prophet about educating children, which, if understood textually, raises the public perception of the necessity of violence in educating children.

For example, in education, there are hadiths related to hitting a child who leaves prayer. If this hadith is only understood textually, then what appears is violence against children. This understanding can contradict the currently developed theory. There are many theories about the impact of violence. Children will receive the impact if they experience abusive behaviour, namely the extent to which the violence affects a child's mindset, feelings, and behaviour patterns.

The most important thing is that this violence has negative implications for children who are victims in particular and in general for those who witness it. Violence committed against children is a form of slow death both physically and mentally, such as bodily injuries, neurological disorders, feelings of inferiority and aggressiveness towards children. It will result in a generation that likes violence as a tool and method to solve problems with violence. ${ }^{6}$

\footnotetext{
${ }^{3}$ M. Nipan Abdul Halim, Anak Saleh Dambaan Keluarga (Yogyakarta: Mitra Pustaka: 2001), h.102.

${ }_{4}$ Tihami dan Sohari Sahrani, Figh Munakahat: Kajian Fikih Nikah Lengkap, (Jakarta: Rajagrafindo Persada, 2009), h. 217.

${ }^{5}$ A. Hamid Sarong, Hukum Perkawinan Islam di Indonesia, (Banda Aceh: Yayasan Pena, 2005), h. 214.

${ }^{6}$ Haedar Nasir, Agama dan Krisis Kemanusiaan Modern (Cet. I; Yogyakarta: Pustaka Pelajar, 1997), h. 58.
} 
In addition to short-term impacts, violence also has long-term impacts, which if allowed to create a culture of violence so that in the end, it is no longer considered violence, but just ordinary things. ${ }^{7}$

The Child Protection Law's main objective is to guarantee and protect children and their rights to live, grow, develop and participate optimally following human dignity and protection from violence and discrimination. Theoretically, Indonesian children are guaranteed to live their lives.

Article 15 of Law Number 35 the Year 2014 states that Every child has the right to receive protection from:

a. Abuse in political activities;

b. Involvement in armed disputes;

c. Involvement in social unrest,

d. Involvement in events that contain elements of violence,

e. Involvement in war; and

f. Sexual crimes."

Article 9 of Law Number 35 of 2014 states that every child has the right to receive education and teaching in personal development and intelligence level according to interests and talents. Every child has the right to get protection in an academic unit from sexual crimes and violence committed by educators, education personnel, fellow students, and other parties.

\section{METHOD}

This research type is classified as qualitative using a library research approach, which is research by writing, clarifying and making data obtained from various written sources. The data collection method uses document techniques (literature study), quoting and analyzing data with document techniques intended to collect related data contained in documents in the form of books, journals and research results in the form of theses, theses and dissertations.

\section{RESULT \& DISCUSSION}

\section{A. Parenting in Islam}

Education in Islamic education literature has many terms. Some of the terms that are often used are Rabba-yarubbu (educating), Allama-yuallimu (knowledge member), addaba-yu'addibu (giving examples in morals), and darrasa-yudarrisu (giving knowledge $)^{8}$. In the following, the meaning of these terms comes from the Koran and hadiths.

\section{Rabba-yurabbi}

Ism fa'il dari rabba-yurabbi adalah murabbi. The word murabbi itself is more oriented towards maintenance, both physical and spiritual maintenance. Therefore, the maintenance process can be related to God's care for His creatures in this case. This

\footnotetext{
${ }^{7}$ Haedar Nasir, Agama dan Krisis Kemanusiaan Modern, h. 297.

${ }^{8}$ Ridwan Abdul Sani dan Muhammad Kadri, Pendidikan Karakter, Mengembangkan Karakter Anak Yang Islami, (Jakarta: Sinar Grafika Offset, 2016), h. 8.
} 
maintenance can also be seen in caring for the parents in raising their children from birth to adulthood. Parents provide full service so that their children grow up physically healthy, have a commendable personality and character. Parents take care of the child by providing food so that the child is healthy, providing clothing to cover his genitals, and avoiding all dangers so that the child feels safe.

Rabba-yurabbi has a masdar, namely tarbiyah. Naquib Al-attas, in his book, states that tarbiyah means to nurture, direct, feed, develop, cause to grow up, protect, make success, and tame. The application of tarbiyah is not limited to humans but also other species such as plants and animals. Therefore, the concept of tarbiyah can be related to chicken farming, fish farming and plantations. Tarbiyah objectives are usually physical because they are only related to material growth.

\section{2. 'Allama-yu'allimu}

The term mu'allim is appropriate given to an educator who transfers and provides knowledge to students about something they did not know before. A mu'allim teaches students starting from they do not know something until they understand it. Masdar from 'allama-yu'allimu is ta'lim. Ta'lim means teaching and education, but in general, ta'lim is only limited to teaching and cognitive education.

\section{Addaba-yu'addibu}

An educator can also be called a mu'addib. Mu'addib comes from the root word addaba-yu'addibu, which means to set an example in morals. The ism fa'il of addabayu'addibu is mu'addib. The term adab is an essential term in Islam and has been widely discussed by scholars regarding its meaning from an Islamic perspective.

\section{Darrasa-yudarrisu}

The word educator can be taken from the word darrasa-yudarrisu. The ism fa'il of the word darrasa-yudarrisu is mudarris. Mudarris is a person who has intellectual and informational sensitivity, updating knowledge and expertise on an ongoing basis, trying to educate students, eradicating ignorance, and training skills according to the talents, interests and abilities of students. ${ }^{9}$

Although there are several different terms for educators, namely Rabba-yurabbi, 'Allama-yu'allimu, addaba-yuaddibu, and darrasa-yudarrisu; however, everything is related to the meaning of educating in Indonesian with the word that the subject is an educator. Based on several educational meanings that have been conveyed, it can be stated that an educator in the concept of Islam is a person who can direct people to the path of truth following the Qur'an and sunnah of the Prophet. So, the definition of education in the concept of Islam is the process by which education can elevate the human (learners) to a more noble position, both in the world and in the hereafter.

Apart from stating that the best Muslims study and teach the Koran, the hadith also describes the requirements for people who want to teach others, namely that the person must master or equip himself with the knowledge to be taught. Of course, the most valuable knowledge is the Koran. Therefore, to be able to teach the Koran, you must

${ }^{9}$ Ridwan Abdul Sani dan Muhammad Kadri, Pendidikan Karakter, Mengembangkan Karakter Anak Yang Islami, (Jakarta: Sinar Grafika Offset, 2016), h. 11 
first learn about the Koran. This is the basis that every educator is obliged to learn and equip themselves with knowledge, especially the knowledge that will be taught to students to understand and get the correct knowledge for educators.

The term education in the Islamic context generally refers to the terms al-tarbiyah, al-ta'dib, and al-ta'lim. Of the three terms, the term that is popularly used in Islamic education is the term al-tarbiyah. The terms al-ta'dib and al-ta'lim are rarely used apart from the different meanings of the three terms above. In terms of Islamic education, experts. Has tried to formulate the notion of Islamic education. Among the very varied boundaries are;

a. Al-Syaibaniy argues that Islamic education is a process of changing individual learners' behaviour in personal life, society, and the environment. This process is carried out utilizing education and teaching as a human and professional activity among the many human professions in society.

b. Muhammad Fadhil al-jamaly defines Islamic education as an effort to develop, encourage and invite students to live more dynamically based on high values and noble life. With this process, it is hoped that students will form a perfect personality, both related to the potential for their intellect, feelings, and actions.

c. Ahmad Tafsir defines Islamic education as guidance provided by a person to develop optimally following Islamic teachings.

d. Ahmadi explained that what is meant by Islamic education is all efforts to maintain and develop human nature in terms of human resources that exist in it towards the formation of a whole human (insan Kamil) following Islamic norms. ${ }^{10}$.

The essence of Islamic education is a Muslim adult who is fearful of consciously directing and guiding students' growth and development (basic abilities) through Islamic teachings towards the maximum point of growth and development.

\section{B. Islamic Law View on Harsh Physcial Parenting}

The command to pray is carried out strictly, because in general, the command to pray has been carried out by parents since before that age. Their parents have invited children from the age of 4 or 5 to pray together. Children do this even by joining or imitating wrong movements. Children at this age follow along, have not carried out well, both movements and reading children, sometimes want to do and sometimes do not want to do it. After the child's age reaches seven years, the parents' orders are strict, unlike when under seven years of age. ${ }^{11}$

The command to pray also means the command to teach how to pray because it is impossible for a child only to be ordered to pray while he cannot do it. "Parents should teach what is needed in prayers, such as the terms and conditions. Parents should order prayers after being taught. Teaching wages are taken from the children's assets if they have assets, and if they do not have the wages, the wages are borne by the guardian".

\footnotetext{
${ }^{10}$ Achmadi, Ideologi Pendidikan Islam Paradigma Humanisme Teosentris, (Yogyakarta: Pustaka Pelajar, 2005), h. 29.

${ }^{11}$ Abdul Majid Khon, Hadist Tarbawi , (Jakarta: Kencana, 2012), h. 263
} 
In education, the commandment is one of the educational tools. So in education, there are orders and prohibitions. This is so that the child understands what is ordered and what is forbidden. Orders are tools to encourage children to do something, while prohibitions are tools to stop a job. Islam recognizes orders and recognizes how important they are. Age 7 years in the child's development is critical or mumayyiz age and educational age. At this age, a child can distinguish between truth and error, right and vanity, and it is at this age, the child has started to think intelligently, captures knowledge, and can communicate perfectly. Therefore, the command to pray strictly starts at this age, and this age is also used as a guideline for school admissions at the elementary level.

The commandment to pray strictly starts at seven years of age and continues to be binding until 9 to 10 years. If ten a child does not want to carry out the command to pray, the parents must beat as the hadith continued above.

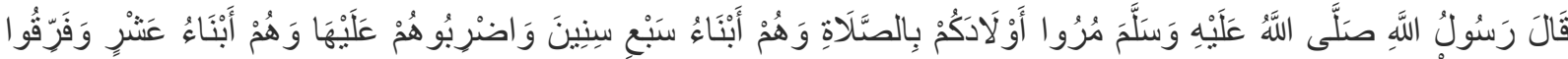

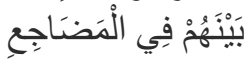

Meaning:

Order your children to pray when they reach the age of seven, and when they reach the age of ten, then beat him if they do not do it, and separate them in his bed..". 12

This hadith commands punishments for children who raise orders or violate prohibitions. The meaning of a blow here is a punishment that is following the conditions. It could be that the one who is beaten in his mind by being isolated or disliking. Alternatively, hit it physically if needed, which in principle, the child can change himself for the better according to orders and prohibitions. Physical blows are defined as punches that are not dangerous, but they can change a child's attitude for the better. Punishment is given to children when they are ten years old because, at this age, a child can withstand a hit as long as it is not in the face. Rasulullah Saw prohibits hitting someone's face, as hasith narrated by Abu Hurairah r.a

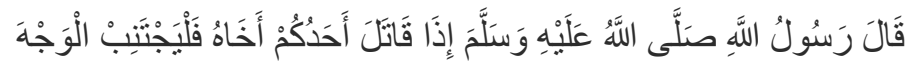

This stroke represents a severe punishment for a child who leaves the prayer. Followers of the Syafi'I School oblige beatings for children who leave prayers on purpose when they are ten years old. ${ }^{13}$ In this hadith, the Prophet Muhammad ordered parents to order their children to pray at the age of 7 and told them to beat as a lesson when children leave prayers, even though small children are not included in the book of obliged people to pray.

12 Abu Daud Sulaiman Sunan Abi Daud, (Beirut:Al-Maktabah al-Ashriyah, 1952),h. 133.

${ }^{13}$ Abad Syams al-Haqq al-Adzim Abadi, Aunul Ma'bud, Syarah Sunan Abu Daud, jilid II (Bairut:

Tayyib Muhamm Dar al-Kutb al-alamiya, 1990), h, 161. 
The fuqaha disagreed over the issue of parents ordering their children to pray and beating them when they did not pray while children had not yet converted.

Imam Malik argues that it is the duty to order his child to perform prayers to be trained. However, children do not have the right to receive beatings. As stated in the Prophet's words "and beat them," he argues that beatings can hurt others while not allowing sunnah matters. ${ }^{14}$

Al-aliqi in sharah al-jam 'al-shaghir said: what is meant by a blow or slap here is a blow that is not dangerous, but an educational stroke that functions so that the child admits his mistake and wants to correct it, and the beating should not be directed at the child's face, because it is identical. One's mentality and honour. Do not occasionally drop the mental or honour of a child. Later the child will become timid, inferior, and so on.

The order to separate the beds between them is intended to avoid slanderous sex on the bed because this ten-year-old is nearing adulthood or nearing adolescence. The development of sex has developed as well as the development of body, spirit, and breath. Shaykh al-Manawi in fath al-Qadir Syam Shaghir said that separating the bed between them was to avoid sexual lust. In the hadith, the combined command of prayer and the order to separate them from the bed give them lessons to keep Allah's commandments. Overall and maintain good relations between fellow humans. Sleeping together between siblings in a bed is not good education, and worries about sexual irregularities either intentionally or unintentionally. Al-thibiy said the commandment to pray and separate them, the beds between them, the beds at a young age are combined because they teach ethics and keep Allah's orders as a whole and teach lessons and relationships between creatures so that they do not stop at suspicious places, then they leave things. -the things that are unclean. ${ }^{15}$ Children's meaning is to stay away from the influence of sex drives or sexual deviations, either promiscuity or watching pornographic films or images or pornographic stories that stimulate children's sexual lust.

In the first seven years, the most crucial issue that must be considered in connection with the powerful influence on children's psychological health is the period of children's freedom of movement and freedom in seeking experiences.

At this time, because the child's brain is not yet fully developed, the readiness and ability of the intellect to accept thoughts, reasoning, and solutions are not yet there. However, on the other hand, the use of the five senses plays a significant role in their activities. By using these senses, children love to run, play, shout, throw and look for everything new. From here then they try to hold whatever is nearby.

In principle, Islam was born intended to lay new social foundations that are antidiscrimination and anti-violence. However, we cannot close our eyes because reality shows that several religious texts, especially Islam, both al-Quran and hadith, can only

${ }_{14}$ Abu Malik Kamal Bin As-sayyid Salim, Shahih Fikih SunnahI, Terj. Wibomo, dkk, (Jakarta:Puataka Azzam, 2007), h. 361.

${ }^{15}$ Abdul Majid Khan, hadist Tarbawi, h. 267 
be censored as a basis. The legitimacy of children to make children as objects of violence. This, in turn, will provide opportunities for justification for law enforcers of violence against children based on religion. Crime does not inherently attach itself to humans. Crime is a violation of the sharah rules that govern interactions between humans and their rabbits, human-human interactions and human-human interactions.

Any form of violence will harm children. Therefore, violence as an alternative solution used by a person in carrying out his obligations as a parent cannot easily be applied but must consider both causes and factors. Parents, children or the environment and what is more important is the consequences that will be caused by the act so that by paying attention to all of this, violence against children will be avoided.

Thus, violence is not the only way out and solve problems related to children. Even if it must be done utilizing violence in solving the problems at hand, it cannot be done to exceed predetermined limits what else until the child is injured. This violates human rights, and Islam does not want that way. Islam considers acts of violence very immoral even if this method is used for the child's promising and future.

The order to beat contained in the hadith is not intended to torture or hurt children, but to give the impression of the child's sincerity of the parents' sincerity in telling him to worship Allah, and this is a reaction from parents (as ordinary people) whose orders are not obeyed by his son. Violence as a form of punishment or efforts made by parents to children in order to carry out their obligations can only be applied when the child has reached the age of 10 years and even then must be done correctly and avoid both physical and psychological injuries and not exceeding the limit, where the child feels harmed physically or psychologically so that it could make him a victim. Besides, parents are not allowed to hit sensitive limbs such as the head and stomach. ${ }^{16}$

The admission of violence carried out by educators, both parents and teachers, is only for disciplinary purposes and nothing else. A child can only be punished for the wrong he has committed and not for the wrong that he is feared will be committed. However, from very different thing from the past, it makes us think again, whether the Islamic method in terms of education for children like that can still be applied at this time. Besides, because the Koran does not allow violence in any form, it is also because violence is no longer considered a sufficiently effective method of educating children.

Suppose we still understand the Prophet's hadith as an allowance of violence in general. In that case, it is possible that the hadiths and verses of the Koran above hint at inconsistencies in Islamic law. However, when viewed more closely, what is contained in the two sources of Islamic law is continuous because the Prophet's hadith is only specific when parents order prayers, with an age limit of 7-10 years. The imposition of violence (beating) against children and is related to age limits also has certain limits. Meaning that even though it is allowed in disciplinary measures, it cannot injure, cause injury, or leave marks on the body. It is also prohibited to hit directly. On the cheeks, chest, back, genitals, and other sensitive places such as the head and abdomen.

${ }^{16}$ Syarh Imam Abu Daud Sulaiman Ibn al Asy'as As-Sajas Tani, Aumil Ma'bud, Kitab Salat Cet III, (Mesir), h.161 
Islam has taught us that to achieve a noble goal, the method we use must be adjusted according to its purpose. In other words, we have to use the methods that we want to achieve and manifest well. Asghar Ali said that this method's problem depends on the temporal context, and we are currently elaborating on the data itself. The concept of anti-violence is indeed an identity that must be used as a foundation and must be applied in everyday life. However, this concept will not work when faced with a social structure that is constantly changing, so this is where perhaps violence cannot be avoided. However, Islam teaches that the methods that are taken must pay attention to moral values.

\section{Harsh Physical Parenting in Indonesian Legal System}

Education and teaching are not synonymous with violence, whether in the past or the present. Nevertheless, violence is often associated with discipline and its application in the world of education. The term "assertive" in fostering a disciplined attitude in children is commonly replaced by the word "hard". This is then supported by the use of violence in fostering disciplinary attitudes in the military world, especially military education when civilian education adopted later military education methods, so this "hard" method is the current term, violence is also taken over in the school environment.

Violent acts in the community are increasingly unsettling in resolving a conflict or problem accompanied by violence. In general, acts of violence can be defined as the deliberate use of physical force, actual threats of violence against oneself, other people or against a group or community, which results in injury or is likely to injure, kill, psychologically harm abnormal growth or loss. There are many forms of violence, including physical violence, verbal violence, psychological violence, economic violence, symbolic violence and neglect. Violence can be carried out by individuals or in groups, carelessly (under pressure) or organized.

Little things can be an excuse for violence. Even violence is carried out without reason. It becomes a big statement if violence occurs from the parent to the child. This is very embarrassing. Parents who are supposed to be good examples for their children instead give bad examples to children. ${ }^{17}$

Education is a fundamental need for humans to perfect their human existence. The need for education is comprehensive for humans to penetrate economic, social, political, religious and cultural status. Therefore, the functions and roles of education are very complex and sustainable towards one particular goal. In the process, education is an effort to develop human potential, physical potential, creative potential, taste and character, so that this potential becomes real. It can function in the course of his life. On that basis, any ongoing education to develop self-potential and improve civilization must have a particular paradigm, namely a "world viewpoint". Each sigma reflects the

${ }_{17}$ Muhammad Ishar Helmi, "Pengadilan Khusus KDRT" Implementasi Gagasan Sistem Peradilan Pidana Terpadu penaganan Kasus-Kasus Kekerasan Terhadap Perempuan (SPPT-PKKTP), Jurnal Cita Hukum (Online), Volume 2 Number 2, (2 December 2014), h. 318-330 
"perspective" of the community in which the education takes place..$^{18}$ Therefore, every society, nation, or state, has an educational paradigm following the community's perspective or country concerned about the world. Concerning the educational paradigm, the Indonesian nation is a nation or religious society accumulated in the formulation of the Pancasila and the 1945 Constitution.

Violence or bullying is often legitimized on the grounds of "enforcing discipline" among children. Thus, physical violence can be said to have become a culture and seems to be a "legalized" mechanism. However, many parties claim that the acts of violence that were carried out were not more than just a form of "resentment" or an outlet for this person to others. Other people can be friends or even children. Many reasons were stated by the perpetrators of violence, both because of children's delinquency.

Realizing this, education has a strategic and functional role in building the order of human life because education always tries to answer the needs and challenges that arise in society due to change. In this frame, the humanization process in education will be inversely proportional to government policies which tend to be regressive. In other words, education is the spearhead to reduce violence.

In reality, the institutionalized education model in schools, both with a general and religious background, has not been able to answer the violence that occurs in society. As stated in Abdurrahman Assegaf's research, schools have become an instrument of violence in the world of education despite the phenomenon of violence in schools. ${ }^{19}$

The cause of violence against children can occur because parents do not understand the meaning of violence and its negative consequences. Parents think that children will be deterred because of physical punishment. On the contrary, they hated and had no respect for him. Violence in education occurs because of a lack of parental love. Parents should treat children as subjects who have individual differences (Eko Indrawanto, 2004). Also, because of the lack of competence of parents in guiding and evaluating their children. Parents overcome and eliminate violent practices that are contrary to educational goals. Violence can occur because a parent has little or no affection for the child, or he is being treated himself harshly.

Besides, violence by parents towards children is caused by the following factors:

a. Lack of parental knowledge that violence is not effective in motivating children or changing behaviour.

b. Persial perceptions of parents in assessing children.

c. There are psychological barriers so that parents are more sensitive and reactive in managing problems.

d. The parents' pattern is to prioritize the factors of obedience and obedience to teaching children in one direction.

Whatever the reasons, the treatment and causes of physical violence that occurred, as explained above, constitute a violation of children's rights and violate human rights.

${ }^{18}$ Djohar, Pendidikan Strategi Alternatif Untuk Pendidikan Masa Depan, (Yogyakarta: LESFI, 2002), h.70

${ }^{19}$ Abdurrahman Assegaf, Pendidikan Tanpa Kekerasan, (Jakarta: Tiara Wacana, 2004), h.2 
Based on the provisions of the Convention on the Rights of the Child, rights are an inseparable part of Human Rights. Therefore, the government, law enforcers and all communities must stop all acts of violence and abuse that occur to children. Law No.4 of 1979 on child welfare explicitly states that children have the right to care for protection from the time they are in their mother's womb. ${ }^{20}$ Besides, children have the right to protection of the environment that endangers or hinders average growth.

\section{CONCLUSION}

Education in Islamic law is a process of guiding and fostering the creation of a maximum fitrah. It leads to the creation of a child's personality as a complete Muslim (al-insan al-Kamil). Through such personal figures, a child is expected to integrate the functions of faith, knowledge and charity in an integral way for the development of a harmonious life both in this world and in the hereafter. To achieve the formation of a complete human being who is entirely faithful and devoted to Allah, Islamic education must be carried out continuously and through a relatively long process and successive stages. This means that Islamic education must also be implemented since humans are still at an early age. They are still children because the provision of religious education in childhood is a significant basis for forming and fostering the Islamic religion in the following periods.

In education, the commandment is one of the educational tools. So in education, there are orders and prohibitions. This is so that children understand what is being ordered and what is prohibited. The command is a tool to encourage children to do something, while prohibition is a tool to stop a job. Islam recognizes orders and recognizes how important they are. Age 7 years in the child's development is critical or mumayyiz age and educational age. At this age, a child can distinguish between truth and error between rights and vanity. At this age, the child has begun to think intelligently to capture knowledge and communicate perfectly. Therefore, the command to pray strictly starts at the age of 7 years and continues and increases up to 9 and 10 years. If ten a child does not carry out the command to pray, the parents are ordered to beat. Followers of the Shafi'i school oblige beatings to children who deliberately leave prayer when they are ten years old. The Prophet Muhammad ordered parents to instruct their children to pray at the age of 7 years and instruct them to beat as a lesson if the child leaves prayer. Even though small children are not included in the book, people are obliged to pray.

${ }^{20}$ Mocha, Faisal Salam, Hukum Acara Peradilan Anak DiIndonesia, (Bandung: Mandar Maju, 2005), h.1 


\section{BIBLIOGRAPHY}

Abad Syams Al-haqq Al-adzim Abadi, Aumul Ma'ruf, Syarak Sunan Abu Daud, Jilid 2,

(Bairut:Thayyib Muhammad Dar al-Kutb Al-alamiyah,1990)

Abad Syams al-Haqq al-Adzim Abadi, Aunul Ma'bud, Syarah Sunan Abu Daud, jilid II

(Bairut: Tayyib Muhamm Dar al-Kutb al-alamiya, 1990)

Abu al- Husain Muslim bin Al-Hujaj al-qusyairi an-naisaburi, sahih Muslim, Jilid II, (Kahira: Dar al-Hadist, 1997)

Abu Daud Sulaiman Sunan Abi Daud, (Beirut:Al-Maktabah al-Ashriyah, 1952)

Abu Malik Kamal Bin As-sayyid Salim, Shahih Fikih SunnahI, Terj. Wibomo, dkk, (Jakarta:Puataka Azzam, 2007)

Achmadi, Ideologi Pendidikan Islam Paradigma Humanisme Teosentris, (Yogyakarta: Pustaka Pelajar, 2005)

Al-Husairi Husain Subhan, Agar Anak Rajin Salat (Jogjakarta: Diva Press, 2011)

Assegaf Abdurrahman, Pendidikan Tanpa Kekerasan, (Jakarta: Tiara Wacana, 2004)

Djohar, Pendidikan Strategi Alternatif Untuk Pendidikan Masa Depan, (Yogyakarta: LESFI, 2002)

Halim Abdul M.Nipan, Anak Saleh Dambaan Keluarga (Yogyakarta: Mitra Pustaka: 2001), h.102.

Kementrian Agama RI, Al-Qur'an dan Meaning (Jakarta: CV. Penerbit Diponegoro, 2010)

Khon Majid Abdul, Hadist Tarbawi , (Jakarta: Kencana, 2012)

M. Arifin, Ilmu Pendidikan Islam, (Jakarat: Bumi Aksara, 1993)

Mocha, Faisal Salam, Hukum Acara Peradilan Anak DiIndonesia, (Bandung: Mandar Maju, 2005)

Nasir Haedar, Agama dan Krisis Kemanusiaan Modern (Cet. I; Yogyakarta: Pustaka Pelajar, 1997)

Oemar At-toumy Al-syaibani, Filsafat Pendidikan Islam, terj. Hasan langgulung, (Jakarta: Bulan Bintang, 1997)

Rahman M. Fauzi, Islamic Parenting, Pendidikan Anak Di Usia Emas, (Jakarta: Erlangga, 2011)

Sani Abdul Ridwan dan Kadri Muhammad, Pendidikan Karakter, Mengembangkan Karakter Anak Yang Islami, (Jakarta: Sinar Grafika Offset, 2016)

Sarong A.Hamid, Hukum Perkawinan Islam di Indonesia, (Banda Aceh: Yayasan Pena, 2005)

Syarh Imam Abu Daud Sulaiman Ibn al Asy'as As-Sajas Tani, Aumil Ma'bud, Kitab Salat Cet III, (Mesir)

Helmi Ishar Muhammad, "Pengadilan Khusus KDRT" Implementasi Gagasan Sistem Peradilan Pidana Terpadu penaganan Kasus-Kasus Kekerasan Terhadap Perempuan (SPPT-PKKTP), Jurnal Cita Hukum (Online), Volume 2 Number 2, (2 December 2014)

Tihami dan Sohari Sahrani, Figh Munakahat: Kajian Fikih Nikah Lengkap, (Jakarta: Rajagrafindo Persada, 2009)

Undang-Undang No. 20 Tahun 2003, Tentang Sistem Pendidikan Nasional 